\title{
Pulmonary responses in current smokers and ex-smokers following a two hour exposure at rest to clean air and fine ambient air particles
}

Milan J Hazucha ${ }^{1,2^{*}}$, Philip A Bromberg ${ }^{1,2}$, John C Lay ${ }^{1,3}$, William Bennett ${ }^{1,2}$, Kirby Zeman ${ }^{1}$, Neil E Alexis ${ }^{1,3}$, Howard Kehrl ${ }^{2,4}$, Ana G Rappold ${ }^{4}$, Wayne E Cascio ${ }^{2}$ and Robert B Devlin ${ }^{4}$

\begin{abstract}
Background: Increased susceptibility of smokers to ambient PM may potentially promote development of COPD and accelerate already present disease.

Objectives: To characterize the acute and subacute lung function response and inflammatory effects of controlled chamber exposure to concentrated ambient fine particles (CAFP) with MMAD $\leq 2.5$ microns in ex-smokers and lifetime smokers.

Methods: Eleven subjects, aged 35-74 years, came to the laboratory 5 times; a training day and two exposure days separated by at least 3 weeks, each with a post-exposure visit $22 \mathrm{~h}$ later. Double-blind and counterbalanced exposures to "clean air" (mean $1.5 \pm 0.6 \mu \mathrm{g} / \mathrm{m}^{3}$ ) or CAFP (mean $108.7 \pm 24.8 \mu \mathrm{g} / \mathrm{m}^{3}$ ) lasted $2 \mathrm{~h}$ with subjects at rest.

Results: At $3 \mathrm{~h}$ post-exposure subjects' DTPA clearance half-time significantly increased by $6.3 \mathrm{~min}$ per $100 \mathrm{\mu g} / \mathrm{m}^{3}$ of CAFP relative to "clean air". At $22 \mathrm{~h}$ post-exposure they showed significant reduction of $4.3 \%$ per $100 \mu \mathrm{g} / \mathrm{m}^{3}$ in FEV and a significant $D_{L} C O$ decrease by $11.1 \%$ per $100 \mu \mathrm{g} / \mathrm{m}^{3}$ of CAFP relative to "clean air". At both $3 \mathrm{~h}$ and $22 \mathrm{~h}$ the HDL cholesterol level significantly decreased by $4.5 \%$ and $4.1 \%$, respectively. Other blood chemistries and markers of lung injury, inflammation and procoagulant activity were within the normal range of values at any condition.

Conclusions: The results suggest that an acute $2 \mathrm{~h}$ resting exposure of smokers and ex-smokers to fine ambient particulate matter may transiently affect pulmonary function (spirometry and $\mathrm{D}_{\mathrm{L}} \mathrm{CO}$ ) and increase DTPA clearance half-time. Except for a post exposure decrease in HDL no other markers of pulmonary inflammation, prothrombotic activity and lung injury were significantly affected under the conditions of exposure.
\end{abstract}

Keywords: CAFP, Chamber exposure, Spirometry, Older smokers, Ex-smokers, DTPA clearance half-time, Lung diffusing capacity, Blood chemistry

\section{Background}

Numerous field and epidemiological studies have shown associations between ambient particulate air pollution exposure and longitudinal changes in peak expiratory flow rates, respiratory symptoms, medication use, mortality and morbidity, including hospital admissions for cardiopulmonary disease [1]. Cigarette smoking can impair

\footnotetext{
* Correspondence: mhazucha@med.unc.edu

${ }^{1}$ Center for Environmental Medicine, Asthma and Lung Biology, University of North Carolina, CB\#7310, 104 Mason Farm Road, Chapel Hill, NC 27599-7310, USA

2Department of Medicine, School of Medicine, University of North Carolina, CB\#7020, Chapel Hill, NC 27599-7020, USA

Full list of author information is available at the end of the article
}

lung function and, therefore, smokers and ex-smokers may be more vulnerable to PM exposure [2]. Despite the concentrated effort by the American Lung Association, the American Heart Association and other agencies to reduce smoking by the US population recent trend estimates show that 1 in 5 adults still smoke. The prevalence rate of current smokers in some states is as high as $28 \%$ [3].

Because smoking is a leading cause of COPD, increased susceptibility of smokers to ambient PM may potentially promote development of COPD. The risk estimate for residents of high pollution areas of developing COPD was higher in past smokers than never smokers [4].

\section{Biomed Central}


Middle-aged current smokers exposed to ambient PM showed a small but statistically significant negative association between pulmonary function $\left(\mathrm{FEV}_{1}\right)$ and $\mathrm{PM}_{10}$ levels [5]. To date, very little is known about whether smokers are more susceptible to PM since only a few epidemiologic studies and no laboratory studies have explored the effects of ambient PM on smokers. Laboratory inhalation study of lung deposition of fine particles has shown an increased deposition in smokers which may potentially result in greater susceptibility to injury by ambient PM [6]. Controlled exposure studies and acute panel studies of nonsmokers have, except for a few reporting a post-exposure decrease in $\mathrm{D}_{\mathrm{L}} \mathrm{CO}$ [7], generally failed to find any consistent lung function changes associated with exposure to PM $[8,9]$.

The general objective of the study was to examine and characterize the acute and subacute lung function response and inflammatory effects of controlled exposure of middle-aged and older ex-smokers and lifetime smokers to concentrated ambient fine particles (CAFP). More specific objectives were to determine whether smokers following controlled exposure to CAFP develop (a) decrements in spirometry or $\mathrm{D}_{\mathrm{L}} \mathrm{CO}$, (b) increased respiratory epithelial permeability as measured by ${ }^{99 \mathrm{~m}} \mathrm{Tc}$-DTPA clearance, and (c) changes in pro-coagulant factors and markers of inflammation, oxidative stress and lung injury in peripheral venous blood.

\section{Results}

\section{Subjects}

Table 1 shows the physical characteristics, smoking history expressed as packs per day per year (pack-years) and baseline pulmonary function of the study participants.
All but two subjects (\#1 and 2) who quit smoking 7 and 10 years ago, respectively, were current smokers.

\section{Particle concentration}

On one of the days each subject was exposed to clean filtered air (CA) with particle concentration ranging from $0.0-5.8 \mu \mathrm{g} / \mathrm{m}^{3}$ (mean $1.5 \pm 0.6$ ). Any gaseous pollutants were diluted by a factor of four. On the other day each subject was exposed to CAFP concentration ranging from $28.6-305.9 \mu \mathrm{g} / \mathrm{m}^{3}$ (mean $108.7 \pm 24.8$ ). Most of the particles came from traffic in the vicinity of the facility.

\section{Pulmonary function}

Immediately following exposure estimated difference in FVC and $\mathrm{FEV}_{1}$ response (Figure 1) between $\mathrm{CA}$ and CAFP was -3.0 and $-1.1 \%$ points per $100 \mu \mathrm{g} / \mathrm{m}^{3}$ of CAFP, respectively. Three hours post-exposure this difference was -3.1 and $-1.8 \%$ points, respectively. None of these changes were statistically significant. However, the difference between CA and CAFP at $22 \mathrm{~h}$ showed a reduction of $4.4 \%(\mathrm{p}=0.101)$ and $4.3 \%$ points $(\mathrm{p}=0.017)$ per $100 \mu \mathrm{g} / \mathrm{m}^{3}$ for FVC and $\mathrm{FEV}_{1}$, respectively. None of the subjects had to use bronchodilator at any time during the study sessions or reported an increased use of bronchodilator between exposure sessions. We found no consistent changes in $\mathrm{FEV}_{1} / \mathrm{FVC}$ either following CA (range $70.2 \%-72.1 \%$ ) or CAFP (range $70.9 \%-72.7 \%$ ) exposures.

The $\mathrm{R}_{\mathrm{AW}}$ at $3 \mathrm{~h}$ and $22 \mathrm{~h}$ following $\mathrm{CA}$ exposure showed $1.7 \%$ and $-0.4 \%$ change from baseline; after CAFP the respective changes were $-0.7 \%$ and $6.0 \%$, with none of the changes being statistically significant.

Table 1 Physical characteristics and baseline pulmonary function

\begin{tabular}{|c|c|c|c|c|c|c|c|c|c|c|c|c|}
\hline $\begin{array}{l}\text { Subj } \\
\#\end{array}$ & Gender & Race & $\begin{array}{l}\text { Age } \\
\text { [yrs] }\end{array}$ & $\begin{array}{c}\text { Height } \\
\text { [cm] }\end{array}$ & $\begin{array}{c}\text { Weight } \\
{[\mathrm{kg}]}\end{array}$ & $\begin{array}{c}\text { Smoking } \\
\text { [pk-yr] }\end{array}$ & BMI & $\begin{array}{l}\mathrm{BSA} \\
{\left[\mathrm{m}^{2}\right]}\end{array}$ & $\begin{array}{c}\text { FEV }_{1} \\
\text { L/s }\end{array}$ & $\begin{array}{c}\text { FEV }_{1} \\
\text { [\% pred] }\end{array}$ & $\begin{array}{c}\mathrm{FEV}_{1} / \mathrm{FVC} \\
{[\%]}\end{array}$ & $\mathrm{D}_{\mathrm{L}} \mathrm{CO}^{* *}$ \\
\hline 1 & $M^{*}$ & $C$ & 74 & 172 & 65.3 & 9.0 & 22.1 & 1.77 & 2.2 & 80.2 & 52.8 & 9.7 \\
\hline 2 & $F^{*}$ & C & 63 & 157 & 60.0 & 40.0 & 24.3 & 1.60 & 1.3 & 61.3 & 58.5 & 16.3 \\
\hline 3 & $F$ & C & 39 & 157 & 114.6 & 48.0 & 46.5 & 2.10 & 1.6 & 60.9 & 57.0 & 20.3 \\
\hline 4 & $M$ & C & 50 & 172 & 77.3 & 31.0 & 26.1 & 1.90 & 3.5 & 103.2 & 78.4 & 25.3 \\
\hline 5 & $M$ & $B$ & 42 & 183 & 75.8 & 39.0 & 22.6 & 1.97 & 3.3 & 92.9 & 72.0 & 35.5 \\
\hline 6 & $F$ & $\mathrm{~B}$ & 40 & 159 & 87.1 & 38.0 & 34.4 & 1.89 & 1.9 & 84.1 & 82.9 & 30.0 \\
\hline 7 & $F$ & C & 46 & 163 & 61.3 & 30.0 & 23.1 & 1.66 & 2.9 & 109.8 & 81.7 & 17.1 \\
\hline 8 & $F$ & $B$ & 55 & 160 & 60.6 & 54.0 & 23.7 & 1.63 & 2.3 & 114.1 & 75.0 & 13.7 \\
\hline 9 & $F$ & C & 35 & 168 & 82.1 & 39.0 & 29.1 & 1.92 & 3.7 & 123.0 & 71.5 & 22.6 \\
\hline 10 & $F$ & $B$ & 53 & 154 & 55.8 & 60.0 & 23.5 & 1.53 & 1.6 & 83.6 & 82.2 & 8.7 \\
\hline 11 & $F$ & $B$ & 35 & 165 & 82.7 & 12.0 & 30.4 & 1.90 & 2.4 & 96.5 & 78.2 & 15.1 \\
\hline Mean & & & 48 & 165 & 74.8 & 27.8 & 36.4 & 1.80 & 2.5 & 91.8 & 72.3 & 20.0 \\
\hline SEM & & & 4 & 3 & 5.2 & 2.2 & 4.7 & 0.10 & 0.2 & 6.1 & 3.5 & 2.6 \\
\hline
\end{tabular}

${ }^{*}$ ex-smoker; ${ }^{*}{ }^{\circ} \mathrm{D}_{\mathrm{L}} \mathrm{CO}$ in $\mathrm{ml} / \mathrm{min} / \mathrm{mm} \mathrm{Hg}$;

$\mathrm{M}=$ male, $\mathrm{F}=$ female; $\mathrm{C}=$ Caucasian, $\mathrm{B}=$ black; $\mathrm{BSA}=$ body surface area; $\mathrm{BMI}=$ body mass index. 


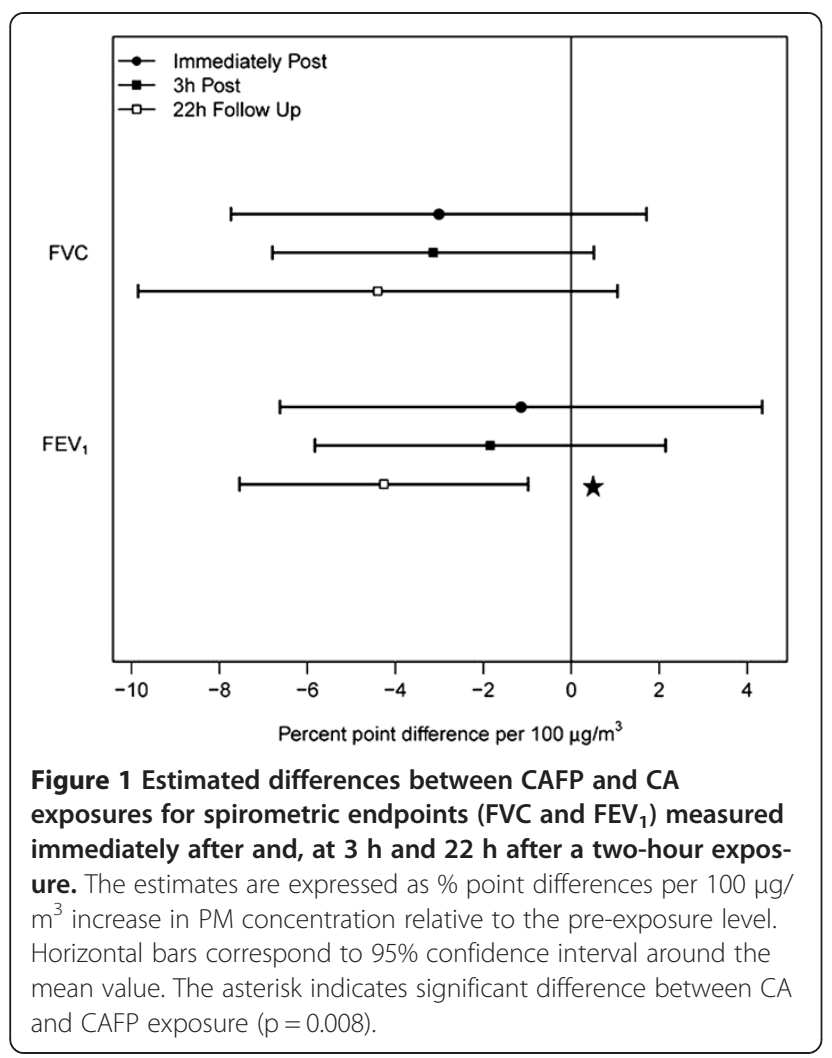

Single breath $\mathrm{D}_{\mathrm{L}} \mathrm{CO}$ decreased significantly by $11.1 \%$ per $100 \mu \mathrm{g} / \mathrm{m}^{3}$ ( $\mathrm{p}=0.035$ one sided) at $22 \mathrm{~h}$ following exposure to CAFP (Figure 2).

\section{${ }^{99 m}$ Tc-DTPA clearance}

Following CA exposure mean ${ }^{99 m}$ Tc-DTPA clearance half-time remained stable at $3 \mathrm{~h}$ and $22 \mathrm{~h}$ post-exposure at 42.6 and $44.4 \mathrm{~min}$, respectively (Figure 3). Exposure to CAFP prolonged the clearance half-time at both $3 \mathrm{~h}$

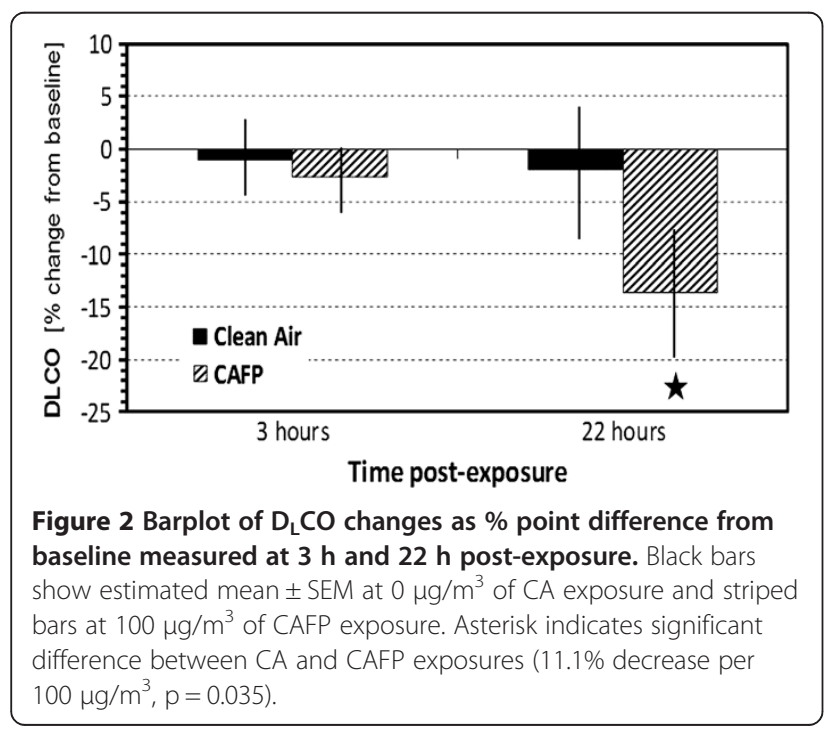

and $22 \mathrm{~h}$ to estimated means of 48.9 and $46.0 \mathrm{~min}$ at $100 \mu \mathrm{g} / \mathrm{m}^{3}$, respectively. The prolongation of clearance half-time at $3 \mathrm{~h}$ by $6.3 \mathrm{~min}$ per $100 \mu \mathrm{g} / \mathrm{m}^{3}$ as compared to CA was statistically significant $(\mathrm{p}<0.026)$. We found no significant changes in the $\mathrm{C} / \mathrm{P}{ }^{99 \mathrm{~m}} \mathrm{Tc}$-DTPA deposition ratios at either post-CAFP exposure time.

\section{NO concentration}

Nasal and exhaled NO concentration changes were small, inconsistent and not statistically significant at any measurement period.

\section{Peripheral venous blood tests}

The changes in CBC with differential WBC are tabulated in Table 2. The absolute neutrophil count at $22 \mathrm{~h}$ post CAFP exposure was statistically significantly lower than at $3 \mathrm{~h}$ after CAFP exposure but not different from baseline. Neither the absolute nor percentage differential WBC count for any other type of cell was significantly different between sessions. The blood chemistry panel variables were within normal range of values at any exposure condition and sessions.

As shown in Figure 4, markers of lung injury, inflammation and procoagulant activity were not significantly affected by either the CA or CAFP exposures. However, as shown in Figure 5, HDL cholesterol was significantly reduced following CAFP relative to CA at $3 \mathrm{~h}(-4.5 \%$ per $\left.100 \mu \mathrm{g} / \mathrm{m}^{3}, \mathrm{p}=0.040\right)$ and $22 \mathrm{~h}\left(-4.1 \%\right.$ per $100 \mu \mathrm{g} / \mathrm{m}^{3}$, $\mathrm{p}=0.011$ ) post CAFP exposure. No other lipid panel variables showed significant changes.

\section{Discussion}

Numerous epidemiologic studies have reported various cardiopulmonary effects including increased acute morbidity and mortality due to ambient exposure of elderly

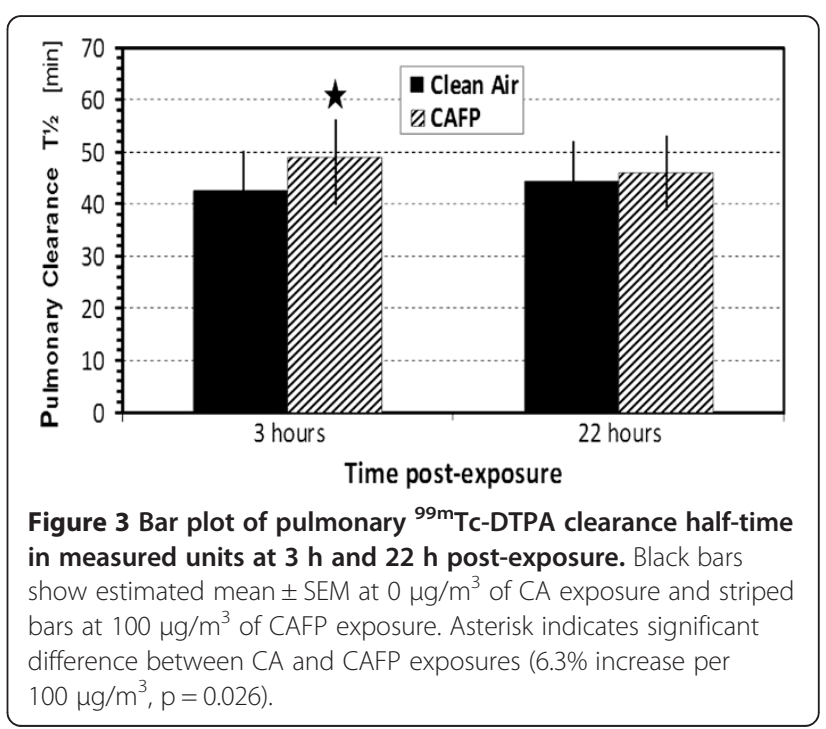


Table 2 Peripheral venous blood absolute cell count (mean \pm SEM )

\begin{tabular}{lcccc}
\hline & & Pre & 3 h post & 22 h post \\
\hline RBC $\left(\times 10^{6} / \mu \mathrm{L}\right)$ & Clean Air & $4.30 \pm 0.09$ & $4.41 \pm 0.11$ & $4.39 \pm 0.15$ \\
& CAFP & $4.49 \pm 0.12$ & $4.52 \pm 0.14$ & $4.41 \pm 0.13$ \\
WBC $\left(\times 10^{3} / \mu \mathrm{L}\right)$ & Clean Air & $5.29 \pm 0.46$ & $5.89 \pm 0.45$ & $5.20 \pm 0.34$ \\
& CAFP & $5.42 \pm 0.37$ & $6.24 \pm 0.45$ & $4.94 \pm 0.23$ \\
Neutrophils $\left(\times 10^{3} / \mu \mathrm{L}\right)$ & Clean Air & $2.99 \pm 0.30$ & $3.18 \pm 0.28$ & $2.87 \pm 0.20$ \\
& CAFP & $3.04 \pm 0.22$ & $3.56 \pm 0.35$ & $2.67 \pm 0.22^{*}$ \\
Lymphocytes $\left(\times 10^{3} / \mu \mathrm{L}\right)$ & Clean Air & $1.74 \pm 0.28$ & $2.07 \pm 0.25$ & $1.76 \pm 0.29$ \\
& CAFP & $1.81 \pm 0.31$ & $2.06 \pm 0.26$ & $1.71 \pm 0.28$ \\
Monocytes $\left(\times 10^{3} / \mu \mathrm{L}\right)$ & Clean Air & $0.40 \pm 0.01$ & $0.45 \pm 0.03$ & $0.38 \pm 0.02$ \\
& CAFP & $0.39 \pm 0.03$ & $0.45 \pm 0.02$ & $0.39 \pm 0.02$ \\
Platelets $\left(\times 10^{3} / \mu \mathrm{L}\right)$ & Clean Air & $231 \pm 16$ & $241 \pm 17$ & $232 \pm 13$ \\
& CAFP & $258 \pm 21$ & $267 \pm 23$ & $241 \pm 18$ \\
\hline
\end{tabular}

${ }^{*} \mathrm{p}=0.0326$ ( $3 \mathrm{~h}$ vs. $\left.22 \mathrm{~h}\right)$

individuals with COPD to fine ambient air PM $[2,10,11]$. Smokers at already increased risk of death from cardiopulmonary disease are even more health compromised when repeatedly exposed to PM [12]. The authors found the strongest respiratory morbidity association with ambient $\mathrm{PM}_{2.5}$ to have zero or one day lag. Although smoking is one of the prominent risk factors for development of COPD that can be aggravated due to

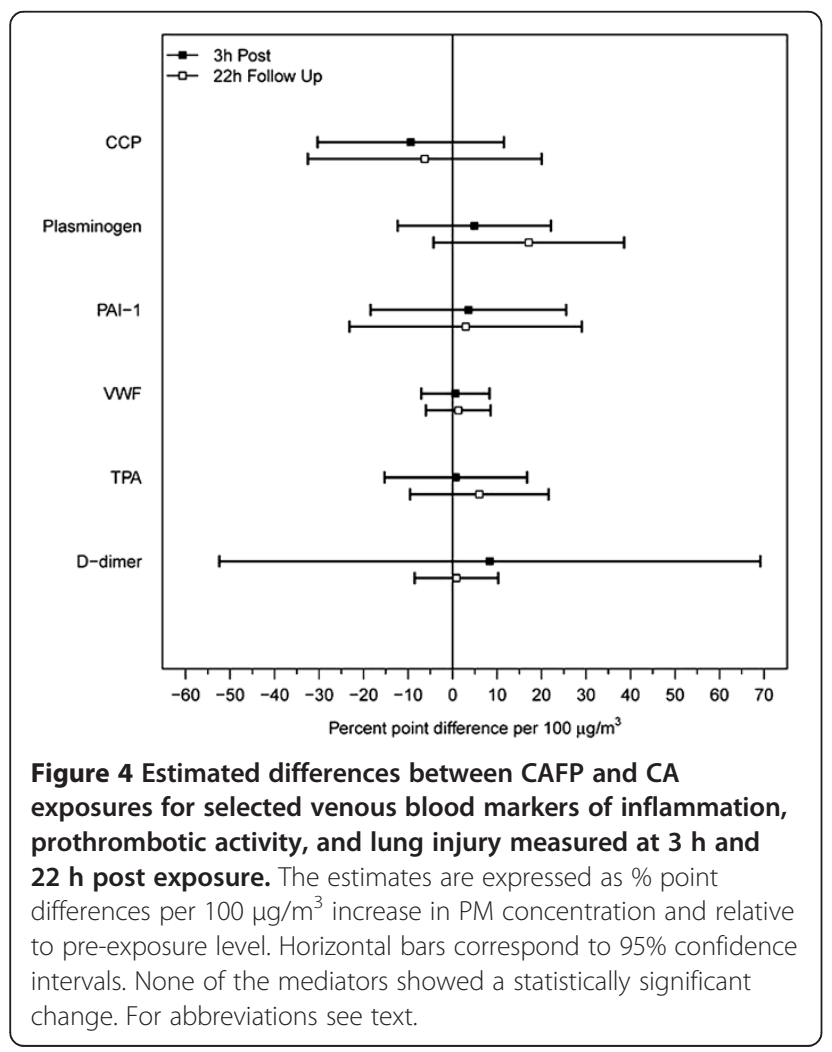

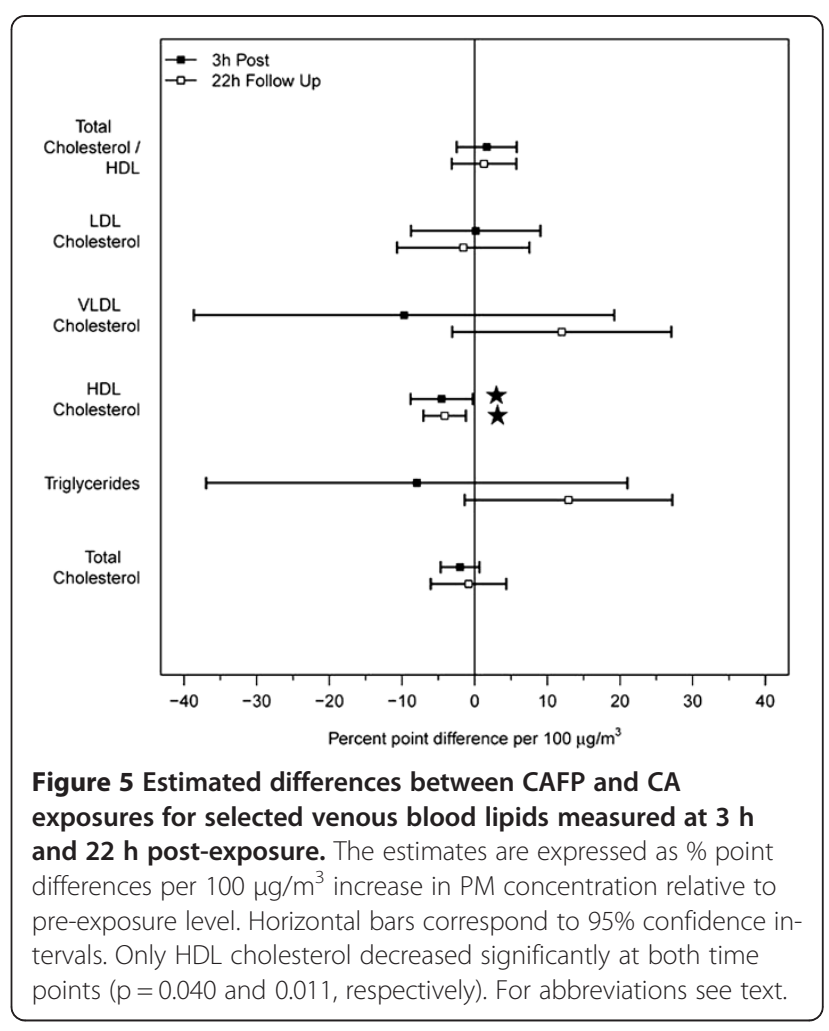

exposure to air pollution [13], very few studies have explored the effects of fine PM and smoking under controlled laboratory conditions. We report a small though not statistically significant decrease in FVC and $\mathrm{FEV}_{1}$ in elderly smokers and subjects with mild COPD immediately after a $2 \mathrm{~h}$ CAFP and CA exposure at rest. Post CAFP exposure the decrements persisted and the $\mathrm{FEV}_{1}$ decrement became statistically significant at $22 \mathrm{~h}$. The reanalysis of data after removing two ex-smokers still showed the decrease in $\mathrm{FEV}_{1}$ to be statistically significant the day after exposure $(22 \mathrm{~h})$. In a study with a similar protocol, both healthy and COPD elderly subjects exposed to CAFP during light intermittent exercise showed no statistically significant spirometric effects although the healthy individuals had a small statistically significant decrease in $\mathrm{SpO}_{2}$ immediately post-exposure suggesting a transient gas exchange impairment [14]. However, in a subsequent study from the same laboratory under similar conditions of exposure, healthy elderly not only showed a statistically significant decrease in $\mathrm{SpO}_{2}$ as in the previous study but a statistically significant decrement in $\mathrm{FEF}_{25-75} 22 \mathrm{~h}$ post-CAFP as well [15]. Thus, the finding of a significant decrease in $\mathrm{FEV}_{1}$ at 22 postCAFP in our younger healthy smokers and ex-smokers is in general agreement with the observation of Gong et al. [15] reflecting mild impairment of large airways in young subjects and of both large and small airways in older individuals. 
In healthy individuals $\mathrm{PM}_{2.5}$ deposits predominantly in the peripheral airways [16]. However, bronchoconstriction of conducting airways will enhance central deposition of fine particles [6]. The epidemiologic study of the Austrian Project on Health Effects of Particulate Matter (AUPHEP) with the population ranging from pre-school children to the elderly has shown that increases in $R_{\mathrm{AW}}$ were most consistently associated with $\mathrm{PM}_{2.5}$ [17]. In our study we observed an insignificant increase in $\mathrm{R}_{\mathrm{AW}}$ at $22 \mathrm{~h}$ post CAFP. Generally, the lung deposition of fine $\mathrm{PM}$ is higher in smokers (and even more so in COPD subjects) when compared to healthy individuals. The enhanced deposition was proportional to the severity of obstruction. In both smokers and COPD subjects the deposition fraction was negatively associated with $\mathrm{FEV}_{1}$ (\% predicted) as well as positively associated with $\mathrm{SR}_{\mathrm{AW}}$ [6]. A computer simulation model showed that in COPD the overall deposition of fine PM is further increased and shifted to proximal airways as compared to healthy. Such a shift most likely increased PM dose per unit of proximal airways surface area [18]. Most likely such redistribution is due to an increased production of mucus combined with airways narrowing of smokers and individuals with COPD. We did not measure fractional lung deposition of fine PM in the present study but our pulmonary function observations are consistent with the above studies. We speculate that the decline in $\mathrm{FEV}_{1}$ at $22 \mathrm{~h}$ following CAFP exposure may be due to an enhanced deposition of fine PM in large airways, and the delay of the effect is consistent with the observation of Pope et al. [12] that the maximal respiratory effects lagged a day following exposure to fine PM.

A substantial component of $\mathrm{PM}_{2.5}$ is ultrafine particles (UFP) of $0.1 \mu \mathrm{m}$ or less. These UFP are preferentially deposited in small airways. A very recent study in healthy subjects has shown that the primary UFP deposition site is the alveolar region. The deposited particles cleared very slowly with no significant elimination over several days [19]. UFP deposition (as a component of fine PM exposure) was reported to be higher in smokers when compared to healthy individuals [6]. In healthy subjects controlled exposure to $50 \mu \mathrm{g} / \mathrm{m}^{3}$ elemental carbon UFP resulted in a small transient increase in $\mathrm{R}_{\mathrm{AW}}$, and statistically significant decrease in $\mathrm{FEF}_{25-75}$ and $\mathrm{D}_{\mathrm{L}} \mathrm{CO}$ at $21 \mathrm{~h}$ post-exposure [7]. The response of our subjects to CAFP was very similar: a small increase in $R_{A W}$, a decrease in $\mathrm{FEV}_{1}$ and $\mathrm{D}_{\mathrm{L}} \mathrm{CO}$ at $3 \mathrm{~h}$ followed by even greater, statistically significant, decrease in the latter two endpoints at $22 \mathrm{~h}$ post exposure. Although the effects UFP may potentially have on alveolar epithelium are yet unclear it is plausible that the gas exchange function of the alveolar region may be compromised. Pietropaoli and colleagues [7] speculated that the UFP effects observed in their study of healthy individuals are due to bronchoconstriction and pulmonary vasoconstriction. Such transient effects are unlikely to have any major health consequences in healthy individuals. However, in smokers who have already reduced spirometric function and $\mathrm{D}_{\mathrm{L}} \mathrm{CO}[20]$ additional reduction in spirometric function and $\mathrm{D}_{\mathrm{L}} \mathrm{CO}$ may further aggravate and even limit subjects' cardiopulmonary function and physical activity.

Although it is unclear what mechanisms may have been involved in $\mathrm{D}_{\mathrm{L}} \mathrm{CO}$ reduction due to $\mathrm{PM}$ inhalation, a transient significant increase in DTPA clearance half-time $\left(\mathrm{T}_{1 / 2}\right)$ (i.e., decrease in clearance rate) at $3 \mathrm{~h}$ post-exposure as compared to CA suggests either decreased pulmonary epithelial permeability or increased thickness of the alveolar-capillary barrier. Few studies have explored the effects of fine PM exposure on DTPA clearance. Inhalation of fine iron oxide particles $\left(12.7 \mathrm{mg} / \mathrm{m}^{3}\right)$ for $30 \mathrm{~min}$ at rest by healthy young volunteers had no significant effects on $\mathrm{D}_{\mathrm{L}} \mathrm{CO}$ and DTPA clearance half-time either at 0.5 or $24 \mathrm{~h}$ post inhalation [21]. Prolonged $24 \mathrm{~h}$ chamber exposure of young healthy exercising individuals to predominantly coarse ambient PM failed to have any significant effects on the bloodgas barrier as measured by DTPA clearance rate [22]. Other studies, however, have shown increased epithelial permeability as assessed by DTPA clearance rate in smokers vs. nonsmokers $[23,24]$. Interpretation of these and of our findings is complicated by likely differences in pre-existing chronic inflammation and changes in airway function and morphology associated with chronic smoking. Evidence for chronic inflammation in our subjects is supported by baseline their DTPA clearance half-time being more than twice as rapid as what we observed previously in healthy non-smoking subjects [21] (mean halftime of 43 vs. 105 min in non-smokers). We speculate that, in our study, fine PM depositing into likely inflamed airways and UFP depositing primarily in the alveolar region induced a transient interstitial edema, effectively thickening the blood-gas barrier which resulted in reduced $\mathrm{D}_{\mathrm{L}} \mathrm{CO}$ and an increased DTPA clearance half-time. This interpretation is supported by the work of Foster et al. [25] which showed that mild airway wall edema due to inflamed airways in sheep reduced the rate of DTPA clearance rate.

The significant respiratory response contrasts with minimal effects on a large number of measured peripheral blood endpoints (coagulation factors, inflammatory mediators, and blood cell count, blood chemistries and lipids). With the exception of changes in HDL we did not find any meaningful associations between the changes in blood variables, PM concentration or pulmonary function changes. Considering a relatively short exposure time at rest it is unlikely that the concentration of the particles was high enough to induce systemic effects. A similar study with a higher level of CAFP and inclusion of light 
exercise also reported a lack of significant changes in CBC, differential WBC and procoagulation factors [14]. On the other hand, Ghio et al. [8] reported neutrophilia in younger individuals exposed to Chapel Hill CAFP for $2 \mathrm{~h}$ while alternating $15 \mathrm{~min}$ exercise (minute ventilation of about $50 \mathrm{~L} / \mathrm{min}$ ) with $15 \mathrm{~min}$ rest to a slightly higher $\mathrm{PM}_{2.5}$ concentration $\left(120.5 \pm 14 \mu \mathrm{g} / \mathrm{m}^{3}\right)$ than in our study. In our middle-aged cohort we observed only a small increase in absolute $\mathrm{WBC}$ at $3 \mathrm{~h}$ post exposure to both $\mathrm{CA}$ and CAFP. The absence of consistent inflammatory, coagulation and blood cell count changes suggest that the respective mechanisms were not sufficiently activated by relatively low fine PM exposure load in our study. Even in studies of elderly where the average fine PM concentration was twice as high as ours the induced changes in the above endpoints were minimal if any $[14,15]$. In our cohort of 11 smokers we did not observe any enhanced pulmonary or inflammatory response in those individuals either. Very recently, however, Rice et al. [26] reported a significant decrease in circulating HDL cholesterol level but no other lipids in welders acutely exposed to primarily $\mathrm{PM}_{2.5}$ welding fumes. Our results parallel these findings, also showing a significant post-exposure decrease in HDL at 3 and $22 \mathrm{~h}$ without any significant changes in other lipids.

\section{Conclusions}

We found that in 11 middle-aged to elderly mostly female smokers, including two ex-smokers, there were statistically significant lung function decrements after a $2 \mathrm{~h}$ exposure to concentrated fine Chapel Hill PM (CAFP) at rest. With respect to our a priori primary endpoint measures we found a significant reduction in $\mathrm{FEV}_{1}$ at $22 \mathrm{~h}$ post-exposure and a significant increase in DTPA clearance half-time at $3 \mathrm{~h}$ post-exposure. The coherence of these observations contrasts with randomness of response in various exploratory endpoints - serum chemistries and protein panels, and procoagulants. These changes were not driven by two ex-smokers since the removal of their data did not change the statistical significance of these primary outcomes. These findings are consistent with mild airways inflammation and plausibly with transient interstitial edema. The findings in other exploratory endpoints such as hematologic, serum chemistry and protein panels, and procoagulants appeared to be random. The lack of consistent inflammatory response makes it difficult to assess the systemic significance of the observed effects. Since these effects developed after resting inhalation of relatively low concentrations of CAFP the lung function changes might be expected to be more pronounced in individuals with pre-existing conditions, with higher inhaled CAFP concentrations and with increased ventilation attendant to exercise.

\section{Methods}

\section{Subjects}

Seventeen current and ex-smokers, aged 35-74 yrs, recruited from the general population who initially qualified for the study approved by the UNC IRB and the EPA but for various technical reasons only 11 participated in the exposure phase of the study. On the day of exposure and until the completion of the study and discharge the next day subjects were not allowed to smoke but were allowed to use their own nicotine gum/patch.

\section{Protocol}

Eligible volunteers came to the laboratory 5 times; a training day and two exposure days with $22 \mathrm{~h}$ follow-up separated by at least 3 weeks. Double-blind and counterbalanced exposures to CA or CAFP with an MMAD of less than 2.5 microns lasted $2 \mathrm{~h}$ with subjects resting during the exposure. During the training session the subjects were familiarized with and performed most of the study procedures. As part of this session ECG leads for $24 \mathrm{~h}$ Holter monitoring were placed on the subjects (Mortara, Milwaukee, WI). Subjects were excluded from further study if the Holter reviewed by a cardiologist showed significant arrhythmia or evidence of ischemia.

Upon arrival in the laboratory on the exposure day, medical personnel ascertained the subject's general health, took vital signs and evaluated respiratory symptoms. Subsequently, the subjects performed pre-exposure lung function tests, had ECG electrodes attached for safety monitoring, had blood samples drawn and entered the exposure chamber with conditions blinded to both the subject and the investigator. ECG and finger pulse $\mathrm{S}_{\mathrm{p}} \mathrm{O}_{2}$ were monitored continuously during the exposure and spirometric measures of lung function were checked midway through the exposures. Subjects were asked to refrain but were not prohibited from using inhaled bronchodilators during exposures; if medication use was necessary subjects were instructed to maintain consistent medication use across the two exposures. After completing post-exposure testing and blood draw the subjects were discharged. The next morning subjects returned to the facility for $22 \mathrm{~h}$ post exposure testing.

\section{Exposure chamber and PM generation}

All exposures were carried out at the EPA Human Studies Facility (HSF) on the University of North Carolina campus at Chapel Hill, NC. A fine particle concentrator [27] installed at the EPA HSF and described earlier [28] was used for this study.

\section{Procedures}

Spirometry was measured before, immediately, $3 \mathrm{~h}$ and $22 \mathrm{~h}$ after exposure using Sensormedics Vmax 229 system 
(Yorba Linda, CA) conforming to recommended ATS/ ERS procedure [29].

The permeability of the respiratory epithelium was assessed at $3 \mathrm{~h}$ and $22 \mathrm{~h}$ post exposure by monitoring the pulmonary clearance of an inhaled radiolabeled tracer molecule ( ${ }^{99 \mathrm{~m}} \mathrm{Tc}$-DTPA) from the lungs into the blood using a gamma camera. The rate of clearance of radioactivity from the thorax serves as an index of alveolar epithelial permeability and the results are reported as the calculated clearance half-time $\left(\mathrm{T}_{1 / 2}\right)$ [21]. Regional deposition within the central $(\mathrm{C})$ and peripheral $(\mathrm{P})$ regions of the lung was examined by calculating a central to peripheral $(\mathrm{C} / \mathrm{P})$ ratio based on counts from the initial one minute dynamic image following deposition of the inhaled radiolabeled DTPA aerosol [30].

As secondary endpoints, we measured $\mathrm{D}_{\mathrm{L}} \mathrm{CO}[31]$ and plethysmographic airway resistance using Sensormedics Vmax system, and exhaled (bag collection) and nasal (on-line) nitric oxide [32] using Sievers 270B analyzer (GE Analytical, Boulder, CO).

Blood was drawn immediately prior to and both $3 \mathrm{~h}$ and $22 \mathrm{~h}$ after exposure to obtain peripheral venous blood cell counts and blood chemistry measurements including a complete blood count (CBC), circulating levels of inflammatory cytokines, serum electrolytes, lipoproteins (triglycerids, total cholesterol, HDL, LDL) and indicators of kidney (creatinine, BUN, BUN/creatinine ratio) and liver (bilirubin, total protein, albumin, globulin, ALP, AST-SGOT, ALT-SGPT, GGT) function. Plasma assays included tPA, PAI-1, vWF, CRP, quantitative CRP, Clara cell 16 protein $(\mathrm{CCP})$, and $\mathrm{D}$-dimer.

\section{Statistical approach}

The primary variables of interest selected a priori were $\mathrm{FEV}_{1}$ and ${ }^{99 \mathrm{~m}} \mathrm{Tc}-\mathrm{DTPA}$ clearance. The other reported endpoints were of secondary interest. All endpoints with the exception of ${ }^{99 \mathrm{~m}}$ Tc-DTPA clearance were acquired at baseline (pre-exposure), $3 \mathrm{~h}$ and $22 \mathrm{~h}$ post-exposure. Spirometry was also measured immediately post-exposure while DTPA clearance was only measured at $3 \mathrm{~h}$ and $22 \mathrm{~h}$ post-exposure. The endpoints with baseline values were expressed as \% of baseline (100*post/pre) to control for day-to-day variability. The differences in responses between CA and CAFP were examined using linear mixed effects models with subject-specific random intercepts to account for repeated measures and subject CAFP exposure level variability. The differences in responses between CA and CAFP were considered separately for each time point (immediately post, $3 \mathrm{~h}$ and $22 \mathrm{~h}$ post-exposure). They were expressed per $100 \mu \mathrm{g} / \mathrm{m}^{3}$ of PM relative to baseline in normalized endpoints (spirometry, $\mathrm{D}_{\mathrm{L}} \mathrm{CO}$ and blood data) and in measured units for ${ }^{99 \mathrm{~m}} \mathrm{Tc}-$ DTPA clearance half-time. $\mathrm{R}$ statistical software (Version 2.11.1) was used for the analysis and to generate plots. To determine statistical significance at $\alpha=0.05$ two-tailed test was used to evaluate all data except $\mathrm{D}_{\mathrm{L}} \mathrm{CO}$ where one-tailed test was used.

In this study a large number of endpoints were measured and so a question of multiple comparisons correction is of concern. For the primary endpoints $\left(\mathrm{FEV}_{1}\right.$, DTPA) multiple comparison adjustment is not appropriate since they were declared as such a priori and are not covariates. While the study was powered on $\mathrm{FEV}_{1}$ changes observed in other studies we measured a number of secondary endpoints not studied under these conditions in this population. Among approximately 40 blood exploratory endpoints, only one (HDL) was found to have a p-value $<0.05$. The other one was $D_{L} C O$. The seemingly significant change of these two endpoints might be due to chance rather than due to CAFP exposure. After adjusting for multiple testing, the HDL and $\mathrm{D}_{\mathrm{L}} \mathrm{CO}$ changes would not have been statistically significant. However, the small sample size may have an impact on the rate of false negative findings particularly when CAFP-induced changes may be small.

\section{Abbreviations}

ALP: Alkaline phosphatase; AST-SGOT: Aspartate aminotransferase; ALTSGPT: Alanine aminotransferase; BUN: Blood urea nitrogen; CA: Clean air; CAFP: Concentrated ambient fine particulates; CBC: Complete blood count; CCP: Clara cell 16 protein; COPD: Chronic obstructive pulmonary disease; CRP: C-reactive protein; $D_{L} C O$ : Lung diffusing capacity for carbon monoxide;

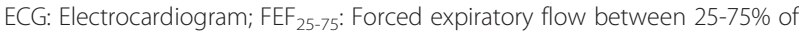
FVC; FEV $_{1}$ : Forced expiratory volume in $1 \mathrm{sec}$; FVC: Forced vital capacity; GGT: Gamma glutamyl transferase; HDL: High density lipoprotein; LDL: Low density lipoprotein; PAl-1: Plasminogen activator inhibitor; PM: Particulate matter; $\mathrm{SpO}_{2}$ : Pulse oximeter oxygen saturation; $\mathrm{R}_{\text {Aw: }}$ : Airway resistance; $\mathrm{SR}_{\text {AW: }}$ : Specific airway resistance; ${ }^{99 \mathrm{~m}}$ Tc-DTPA: Technetium-99m diethylene triamine pentaacetic acid; tPA: Tissue plasminogen activator; VWF: Von Willebrand factor antigen level; UFPM: Ultrafine particulate matter.

\section{Competing interests}

The authors declare that they have no competing interests.

\section{Authors' contributions}

Conception and design: MJH, PAB, RBD, WB, NEA, WEC. Acquisition of data: $\mathrm{MJH}, \mathrm{WB}, J \mathrm{CL}, \mathrm{KZ}, \mathrm{HK}$. Analysis and interpretation of data: MJH, AGR, NA, PAB, $J$, RBD Drafting and revisions of the manuscript: $M J H, P A B, J L, W B, N A, A G R$, WEC, RBD. All authors read and approved the final manuscript.

\section{Acknowledgements}

This research was funded by the United States Environmental Protection Agency through cooperative agreement CR83346301 with the Center for Environmental Medicine, Asthma and Lung Biology at the University of North Carolina at Chapel Hill. This document has been reviewed in accordance with U.S. Environmental Protection Agency Policy and approved for publication. The views expressed in this article are those of the authors and do not necessarily represent the views of policies of the U.S. Environmental Protection Agency. The authors are indebted to MaryAnn Bassett and Debra Levin for medical assistance with subjects; and to Lisa Dailey, Jacqueline Stonehuerner, Jacqueline Carter, Joleen Soukup, Shirley Harder, Robert Silbajoris and Martin Case for their technical assistance in the execution of this study.

\section{Author details}

${ }^{1}$ Center for Environmental Medicine, Asthma and Lung Biology, University of North Carolina, CB\#7310, 104 Mason Farm Road, Chapel Hill, NC

27599-7310, USA. ²Department of Medicine, School of Medicine, University of North Carolina, CB\#7020, Chapel Hill, NC 27599-7020, USA. ${ }^{3}$ Department of 
Pediatrics, School of Medicine, University of North Carolina, Chapel Hill, NC 7220, USA. ${ }^{4}$ Environmental Public Health Division, MD 58B, National Health and Environmental Effects Research Laboratory, U.S. EPA, Research Triangle Park, NC 27711, USA

Received: 1 May 2013 Accepted: 13 November 2013 Published: 18 November 2013

\section{References}

1. Schwartz J: Air pollution and hospital admissions for the elderly in Detroit, Michigan. Am J Respir Crit Care Med 1994, 150:648-655.

2. U.S. EPA: Integrated Science Assessment for Particulate Matter. Washington, DC: U.S. Environmental Protection Agency; 2009. EPA/600/R08/139F

3. Center for Disease Control and Prevention: State-specific prevalence and trends in adult cigarette smoking_United States, 1998-2007. MMWR Morb Mortal Wkly Rep 2009, 58:221-226.

4. Hodgkin JE, Abbey DE, Euler GL, Magie AR: COPD prevalence in nonsmokers in high and low photochemical air pollution areas. Chest 1984, 86:830-838.

5. Pope CA III, Kanner RE: Acute effects of PM10 pollution on pulmonary function of smokers with mild to moderate chronic obstructive pulmonary disease. Amer Rev Respir Dis 1993, 147:1336-1340.

6. Kim CS, Kang TC: Comparative measurement of lung deposition of inhaled fine particles in normal subjects and patients with obstructive airway disease. Am J Respir Crit Care Med 1997, 155:899-905.

7. Pietropaoli AP, Frampton MW, Hyde RW, Morrow PE, Oberdorster G, Cox C, Speers DM, Frasier LM, Chalupa DC, Huang LS, Utell MJ: Pulmonary function, diffusing capacity, and inflammation in healthy and asthmatic subjects exposed to ultrafine particles. Inhal Toxicol 2004, 16(Suppl 1):59-72.

8. Ghio AJ, Kim C, Devlin RB: Concentrated ambient particles induce a neutrophilic lung inflammation in healthy volunteers. Am J Respir Crit Care Med 2000, 162:981-988.

9. Samet JM, Graff D, Berntsen J, Ghio AJ, Huang YC, Devlin RB: A comparison of studies on the effects of controlled exposure to fine, coarse and ultrafine ambient particulate matter from a single location. Inhal Toxicol 2007, 19(Suppl 1):29-32.

10. Schwartz J: What are people dying of on high air pollution days? Environ Res 1994, 64:26-35.

11. Burnett RT, Cakmak S, Brook JR, Krewski D: The role of particulate size and chemistry in the association between summertime ambient air pollution and hospitalization for cardiorespiratory diseases. Environ Health Perspect 1997, 105:614-620

12. Pope CA, Burnett RT, Thurston GD, Thun MJ, Calle EE, Krewski D, Godleski JJ: Cardiovascular mortality and long-term exposure to particulate air pollution - Epidemiological evidence of general pathophysiological pathways of disease. Circulation 2004, 109:71-77.

13. Eisner MD, Anthonisen N, Coultas D, Kuenzli N, Perez-Padilla R, Postma D, Romieu I, Silverman EK, Balmes JR: An official American thoracic society public policy statement: novel risk factors and the global burden of chronic obstructive pulmonary disease. Am J Respir Crit Care Med 2010, 182:693-718.

14. Gong H, Linn WS, Terrell SL, Anderson KR, Clark KW, Sioutas C, Cascio WE, Alexis N, Devlin RB: Exposures of elderly volunteers with and without chronic obstructive pulmonary disease (COPD) to concentrated ambient fine particulate pollution. Inhal Toxicol 2004, 16:731-744.

15. Gong H, Linn WS, Clark KW, Anderson KR, Geller MD, Sioutas C: Respiratory responses to exposures with fine particulates and nitrogen dioxide in the elderly with and without COPD. Inhal Toxicol 2005, 17:123-132.

16. Scheuch G, Philipson K, Falk R, Anderson M, Svartengren M, Stahlhofen W, Camner P: Retention of Particles Inhaled in Boli with and Without Induced Bronchoconstriction. Exp Lung Res 1995, 21:901-916.

17. Neuberger M, Schimek MG, Horak F, Moshammer H, Kundi M, Frischer T, Gomiscek B, Puxbaum H, Hauck H: Auphep-Team: Acute effects of particulate matter on respiratory diseases, symptoms and functions: epidemiological results of the Austrian Project on Health Effects of Particulate Matter (AUPHEP). Atmos Environ 2004, 38:3971-3981.

18. Segal RA, Martonen TB, Kim CS, Shearer M: Computer simulations of particle deposition in the lungs of chronic obstructive pulmonary disease patients. Inhal Toxicol 2002, 14:705-720.
19. Sanchez-Crespo A, Klepczynska-Nystrom A, Lundin A, Larsson BM, Svartengren M: (111)Indium-labeled ultrafine carbon particles, a novel aerosol for pulmonary deposition and retention studies. Inhal Toxicol 2011, 23:121-128.

20. Verbanck S, Schuermans D, Meysman M, Paiva M, Vincken W: Noninvasive assessment of airway alterations in smokers - The small airways revisited. Am J Respir Crit Care Med 2004, 170:414-419.

21. Lay JC, Zeman KL, Ghio AJ, Bennett WD: Effects of inhaled iron oxide particles on alveolar epithelial permeability in normal subjects. Inhal Toxicol 2001, 13:1065-1078.

22. Brauner EV, Mortensen J, Moller P, Bernard A, Vinzents P, Wahlin P, Glasius M, Loft S: Effects of ambient Air particulate exposure on blood-gas barrier permeability and lung function. Inhal Toxicol 2009, 21:38-47.

23. Dusser DJ, Minty BD, Collignon MG, Hinge D, Barritault LB, Huchon GJ: Regional respiratory clearance of aerosolized 99mTc-DTPA: Posture and smoking effects. J Appl Physiol 1986, 60:2000-2006.

24. O'Doherty MJ, Peters AM: Pulmonary technetium- $99 \mathrm{~m}$ diethylene triamine pentaacetic acid aerosol clearance as an index of lung injury. Eur J Nucl Med 1997, 24:81-87.

25. Foster WM, Wagner EM: Bronchial edema alters Tc-99 m-DTPA clearance from the airway surface in sheep. J Appl Physiol 2001, 91:2567-2573.

26. Rice MB, Cavallari J, Fang S, Christiani D: Acute decrease in HDL cholesterol associated with exposure to welding fumes. J Occup Environ Med 2011, 53:17-21.

27. Demokritou P, Gupta T, Ferguson S, Koutrakis P: Development of a high-volume concentrated ambient particles system (CAPS) for human and animal inhalation toxicological studies. Inhal Toxicol 2003, 15:111-129.

28. Ghio AJ, Huang YCT: Exposure to concentrated ambient particles (CAPs): A review. Inhal Toxicol 2004, 16(Suppl 1):53-59.

29. Miller MR, Hankinson J, Brusasco V, Burgos F, Casaburi R, Coates A, Crapo R, Enright P, Van der Grinten CPM, Gustafsson P, Jensen R, Johnson DC Maclntyre N, Mckay R, Navajas D, Pedersen OF, Pellegrino R, Viegi G, Wanger J: Standardisation of spirometry. Eur Respir J 2005, 26:319-338.

30. Lay JC, Alexis NE, Zeman KL, Peden DB, Bennett WD: In vivo uptake of inhaled particles by airway phagocytes is enhanced in patients with mild asthma compared with normal volunteers. Thorax 2009, 64:313-320.

31. ATS/ERS: Standardization of the single-breath determination of carbon monoxide uptake in the lung. Eur Resp J 2005, 26:720-725.

32. ATS/ERS: Recommendations for standardized procedures for the online and offline measurements of exhaled lower respiratory nitric oxide and nasal nitric oxide. Am J Respir Crit Care Med 2005, 171:912-930

doi:10.1186/1743-8977-10-58

Cite this article as: Hazucha et al:: Pulmonary responses in current smokers and ex-smokers following a two hour exposure at rest to clean air and fine ambient air particles. Particle and Fibre Toxicology 2013 10:58.

\section{Submit your next manuscript to BioMed Central and take full advantage of:}

- Convenient online submission

- Thorough peer review

- No space constraints or color figure charges

- Immediate publication on acceptance

- Inclusion in PubMed, CAS, Scopus and Google Scholar

- Research which is freely available for redistribution 